\title{
Genetic alterations in lung adenocarcinoma with a micropapillary component
}

\author{
MASASHI FURUKAWA ${ }^{1}$, SHINICHI TOYOOKA ${ }^{1,2}$, KOUICHI ICHIMURA $^{3}$, HIROMASA YAMAMOTO $^{1}$, \\ JUNICHI SOH ${ }^{1}$, SHINSUKE HASHIDA ${ }^{1,2}$, MAMORU OUCHIDA ${ }^{4}$, KAZUHIKO SHIEN $^{1,2}$, \\ HIROAKI ASANO $^{1}$, KAZUNORI TSUKUDA ${ }^{1}$ and SHINICHIRO MIYOSHI ${ }^{1}$

\begin{abstract}
Departments of ${ }^{1}$ Thoracic, Breast and Endocrinological Surgery, ${ }^{2}$ Clinical Genomic Medicine, ${ }^{3}$ Pathology, and ${ }^{4}$ Molecular Genetics, Okayama University Graduate School of Medicine, Dentistry

and Pharmaceutical Sciences, Okayama, Okayama 700-8558, Japan
\end{abstract}

Received May 22, 2015; Accepted November 25, 2015

DOI: $10.3892 / \operatorname{mco} .2015 .690$

\begin{abstract}
Pulmonary adenocarcinoma (PA) with a micropapillary component (PA-MPC) is known as an aggressive subtype of PA. The molecular profiles of PA-MPC have not been well characterized. The pathological reports of patients who underwent surgical resection for lung cancer between April, 2004 and May, 2012 were reviewed. Of the 674 patients diagnosed with PA, 28 were found to have MPC. A total of 138 resected PAs without MPC were selected in the same period to serve as age-, gender- and smoking status-matched controls to the PA-MPC group. Mutational status was determined by the following two methods: SNaPshot assay based on multiplex polymerase chain reaction (PCR), primer extension and capillary electrophoresis that was designed to assess 38 somatic mutations in 8 genes [AKT1, $B R A F$, endothelial growth factor receptor $(E G F R)$, Kirsten rat sarcoma viral oncogene homolog (KRAS), mitogen-activated protein kinase kinase 1 , neuroblastoma RAS viral oncogene homolog, phosphatidylinositol-4,5-bisphosphate 3-kinase, catalytic subunit $\alpha$ (PIK3CA) and phosphatase and tensin homolog]; and a PCR-based sizing assay that assesses $E G F R$ exon 19 (deletions), EGFR exon 20 (insertions) and human epidermal growth factor receptor 2 exon 20 (insertions). Echinoderm microtubule-associated protein-like 4-anaplastic lymphoma kinase fusion gene $(E M L 4-A L K)$ was screened by ALK immunohistochemistry and confirmed using the reverse transcription PCR assay and the break-apart fluorescence in situ hybridization assay. Regarding genetic alterations, 13 (46.4\%) of the 28 PA-MPCs harbored mutually exclusive mutations:
\end{abstract}

Correspondence to: Professor Shinichi Toyooka, Department of Clinical Genomic Medicine, Okayama University Graduate School of Medicine, Dentistry and Pharmaceutical Sciences, 2-5-1 Shikata-cho, Kita-ku, Okayama, Okayama 700-8558, Japan

E-mail: toyooka@md.okayama-u.ac.jp

Key words: micropapillary adenocarcinoma, lung cancer, endothelial growth factor receptor gene, Kirsten rat sarcoma viral oncogene homolog, echinoderm microtubule-associated protein-like 4-anaplastic lymphoma kinase fusion gene
$9(32.1 \%)$ EGFR mutations, 1 (3.6\%) KRAS mutation and $3(10.7 \%) E M L 4-A L K$ fusion genes. PAs without MPC harbored 42 (30.4\%) EGFR mutations, 17 (12.3\%) KRAS mutations, 3 (2.2\%) EML4-ALK fusion genes and $1(0.7 \%)$ PIK3CA mutation. EML4-ALK fusion genes appeared to occur significantly more frequently in PA-MPCs compared with PAs without MPC $(\mathrm{P}=0.027)$. Although the sample size was small, our study suggests that the molecular pathogenesis of PA-MPC may be different from that of other adenocarcinomas.

\section{Introduction}

Lung cancer is one of the most refractory malignancies and the leading cause of cancer-related mortality worldwide (1-3). Lung cancer is mainly classified into two categories, small-cell lung cancer (SCLC) and non-SCLC (NSCLC). Recent advances in lung cancer research have identified several novel therapeutic agents, such as pemetrexed and bevacizumab (4), which target non-squamous cell carcinomas, i.e., mainly adenocarcinomas; thus, an accurate subclassification of NSCLC is required. Furthermore, the use of molecular-targeted agents, such as gefitinib and erlotinib, necessitated the subclassification of adenocarcinomas from the aspect of molecular characteristics $(5,6)$. Thus, the existing classifications of the World Health Organization (WHO) in 2004 required a revision. The new international, multidisciplinary classification of lung adenocarcinoma, was proposed by the International Association for the Study of Lung Cancer (IASLC), the American Thoracic Society (ATC) and the European Respiratory Society (ERS) (7). In this classification, pulmonary adenocarcinoma (PA) with a micropapillary component (PA-MPC) was recommended as a new subtype of PA in addition to the lepidic, acinar, papillary and solid subtypes defined in the 2004 WHO classification (8). MPC was defined as tumor cells growing in papillary tufts lacking fibrovascular cores that may float within alveolar spaces (Fig. 1) (9,10). PA-MPC has been associated with an aggressive clinical course compared with traditional papillary adenocarcinoma and bronchioloalveolar carcinoma (9,11-13). PA-MPC is frequently encountered in non-smokers, with intralobar satellites, and frequently metastasizes to the contralateral lung, mediastinal lymph nodes, bone and adrenal 
glands, with a high mortality rate (11-14). Although PA-MPC represents a unique form of PA, its molecular profile is yet to be elucidated. In the present study, PA-MPC was analyzed for the common genetic mutations in PA, including endothelial growth factor receptor gene $(E G F R)$, Kirsten rat sarcoma viral oncogene homolog $(K R A S)$ and echinoderm microtubule-associated protein-like 4-anaplastic lymphoma kinase fusion gene (EML4-ALK) to determine whether a distinct genetic profile was associated with this histopathological growth pattern.

\section{Patients and methods}

Patients. The pathological reports of patients who underwent surgical resection for lung cancer between April, 2004 and May, 2012 at the Okayama University Hospital (Okayama, Japan) were reviewed. Of the 674 patients diagnosed with PA, 28 were found to have MPC. The ratio of MPC varied widely (3-80\%) among these 28 patients. A total of 138 resected PAs without MPC were randomly selected in the same period to serve as age-, gender- and smoking status-matched controls to the PA-MPC cases (Table I). Our Institutional Review Board approved this study's protocol and informed consent was obtained from all the patients.

DNA and RNA extraction. Genomic DNA was obtained from primary tumors by standard phenol-chloroform (1:1) extraction followed by ethanol precipitation, or by using the DNeasy Tissue kit (Qiagen, Valencia, CA, USA). Total RNA was extracted from primary tumors using the RNeasy Mini kit (Qiagen) according to the manufacturer's protocol. Oligo(dT)-primed cDNA was synthesized using the High-Capacity cDNA Reverse Transcription kit (Applied Biosystems, Foster City, CA, USA) with DNase treatment.

Genotype screening. Using DNA derived from frozen tumor specimens, genotyping was performed by SNaPshot, a targeted mutational analysis assay designed by $\mathrm{Su}$ et al (15). The platform involves two methods: a screen (SNaPshot) based on multiplex polymerase chain reaction (PCR), primer extension and capillary electrophoresis that was designed to assess 38 somatic mutations in 8 genes [ $(A K T 1, B R A F, E G F R$, $K R A S$, mitogen-activated protein kinase kinase $1(M E K 1)$, neuroblastoma RAS viral oncogene homolog (NRAS), phosphatidylinositol-4,5-bisphosphate 3-kinase, catalytic subunit $\alpha$ (PIK3CA) and phosphatase and tensin homolog (PTEN)]; and a PCR-based sizing assay that assesses EGFR exon 19 (deletions), EGFR exon 20 (insertions) and human epidermal growth factor receptor 2 (HER2) exon 20 (insertions).

Detection of EGFR and KRAS mutations. PCR-based assays or direct sequencing were performed to confirm the results if mutations of EGFR and KRAS were detected by the SNaPshot assay.

The EGFR mutational status was determined using a PCR-based length polymorphism and restriction fragment length polymorphism assay, as previously reported (16). Briefly, the common deletions of exon 19 were distinguished from the wild-type based on PCR product length polymorphisms using $12 \%$ polyacrylamide gel electrophoresis (PAGE) via ethidium bromide staining. For the exon 21 L858R muta- tion, Sau96I digestion, which specifically digests the mutant type, was performed prior to $12 \%$ PAGE.

The KRAS mutations in codons 12 and 13 were examined using PCR-based direct sequencing on an ABI PRISM 3130xl Genetic Analyzer (Applied Biosystems), as previously reported (17-19).

Detection of EML4-ALK fusion events. EML4-ALK fusion was screened by ALK immunohistochemistry (IHC) and confirmed by reverse transcription (RT)-PCR assay and fluorescence in situ hybridization (FISH) analysis.

ALK IHC. Unstained paraffin-embedded sections were deparaffinised in xylene, hydrated through, and rinsed in distilled water. Heat-induced epitope retrieval was performed with EnVision FLEX Target Retrieval Solution, High pH (Dako, Carpinteria, California, USA). The slides were then incubated at room temperature with mouse anti-ALK monoclonal antibody (clone 5A4; dilution, 1:100; cat. no. ab17127; Abcam) for $30 \mathrm{~min}$. The slides were incubated at room temperature with EnVision FLEX+Mouse Linker (Dako) for 15 min. The immune complexes were then detected with the dextran polymer reagent (Fig. 2A) $(20,21)$.

$R T-P C R$. The primers used to identify the $E M L 4-A L K$ fusion transcript were selected to enable the detection of all possible in-frame fusions of EML4 to exon 20 of $A L K$, in which the kinase domain of $A L K$ would be preserved. The forward primers used were EML4 72F (5'-GTCAGCTCTTGAGTC ACGAGTT-3') and fusion-RT-S (5'-GTGCAGTGTTTAGCA TTCTTGGGG-3'); the reverse primer was $A L K$ 3078RR (5'-ATCCAGTTCGTCCTGTTCAGAGC-3') (22). PCR was performed for EML4-ALK under the following conditions: $94^{\circ} \mathrm{C}$ for $10 \mathrm{~min}$, followed by 35 cycles of denaturation at $94^{\circ} \mathrm{C}$ for $1 \mathrm{~min}$, annealing at $64^{\circ} \mathrm{C}$ for $1 \mathrm{~min}$ and polymerization at $72^{\circ} \mathrm{C}$ for $1 \mathrm{~min}$, with a final extension step at $72^{\circ} \mathrm{C}$ for $7 \mathrm{~min}$. RT-PCR for GAPDH expression as an internal control was performed under the same conditions in each tumor sample.

FISH. FISH was performed on formalin-fixed, paraffin-embedded tumor tissues using a break-apart probe to the ALK gene (Vysis LSI ALK Dual Color, Break Apart Rearrangement Probe; Abbott Molecular, Abbott Park, IL, USA) as per the manufacturer's instructions. Cases were defined as FISH-positive when there was a $>15 \%$ split signal in the tumor cells (Fig. 2B) $(23,24)$.

Statistical analysis. Differences in statistical significance among the categorized groups were compared using the Chi-square test or the Student's t-test. An analysis of overall survival and disease-free survival was performed using the Kaplan-Meier method with the log-rank test. The data were analyzed using SPSS v22.0 software (IBM SPSS, Armonk, $\mathrm{NY}$, USA). $\mathrm{P}<0.05$ was considered to indicate a statistically significant difference for each analysis.

\section{Results}

Genetic alterations in clinical samples. Regarding genetic alterations, 13 (46.4\%) of the 28 PA-MPCs harbored mutually 
Table I. Patient characteristics.

\begin{tabular}{lccc}
\hline & \multicolumn{2}{c}{ MPC } & \\
\cline { 2 - 3 } Characteristics & $\begin{array}{c}\text { Positive } \\
(\mathrm{n}=28)\end{array}$ & $\begin{array}{c}\text { Negative } \\
(\mathrm{n}=138)\end{array}$ & P-value \\
\hline Age (years) & $65.3 \pm 11.0$ & $66.0 \pm 9.8$ & NS \\
Gender & & & NS \\
Male & 21 & 101 & \\
Female & 7 & 37 & NS \\
Smoking history & & & \\
Smoker & 20 & 100 & $<0.001^{\mathrm{a}}$ \\
Non-smoker & 8 & 38 & \\
Pathological stage & & & \\
I & 13 & 104 & \\
II & 7 & 12 & \\
III & 41 & 8 & \\
IV & 4 & 4 & \\
\hline
\end{tabular}

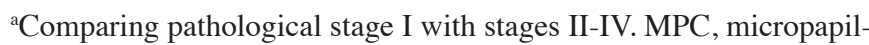
lary component; NS, non-significant.

Table II. Association between MPC and genetic alterations.

\begin{tabular}{llcc}
\hline & \multicolumn{2}{c}{ MPC, patient no. $(\%)$} & \\
\cline { 2 - 3 } Genes & $\begin{array}{c}\text { Positive } \\
(\mathrm{n}=28)\end{array}$ & $\begin{array}{c}\text { Negative } \\
(\mathrm{n}=138)\end{array}$ & P-value \\
\hline EGFR & $9(32.1)$ & $42(30.4)$ & 0.9 \\
KRAS & $1(3.6)$ & $17(12.3)$ & 0.2 \\
EML4-ALK & $3(10.7)$ & $3(2.2)$ & 0.027 \\
\hline
\end{tabular}

MPC, micropapillary component; $E G F R$, endothelial growth factor receptor gene; KRAS, Kirsten rat sarcoma viral oncogene homolog; EML4-ALK, echinoderm microtubule-associated protein-like 4-anaplastic lymphoma kinase fusion gene.

exclusive mutations: 9 (32.1\%) EGFR mutations, 1 (3.6\%) KRAS mutation and 3 (10.7\%) EML4-ALK fusion genes. PAs without MPC harbored 42 (30.4\%) EGFR mutations, $17(12.3 \%)$ KRAS mutations, 1 (0.7\%) PIK3CA mutation and $3(2.2 \%) E M L 4-A L K$ fusion genes in a mutually exclusive manner, except that 1 case had EGFR G719A and L861Q mutations. There were no mutations in the $A K T 1, B R A F, M E K 1$, NRAS, PTEN or HER2 genes in either group. EML4-ALK fusion genes appeared to occur significantly more frequently in PA-MPCs compared with PA without MPC $(\mathrm{P}=0.027)$ (Table II). Regarding the EGFR and KRAS mutational status, the results of the SNaPshot assay were consistent with those of PCR-based assays or direct sequencing.

Effect of PA-MPCs on clinical outcome. To confirm the clinical outcome of PA-MPC, 11 cases with pathological stage IA PA-MPC were compared with 65 cases with pathological
Table III. Association among MPC, patient characteristics and genetic alterations in pathological stage IA lung adenocarcinoma.

\begin{tabular}{|c|c|c|c|}
\hline \multirow[b]{2}{*}{ Characteristics } & \multicolumn{2}{|c|}{ MPC } & \multirow[b]{2}{*}{ P-value } \\
\hline & $\begin{array}{c}\text { Positive } \\
(n=11)\end{array}$ & $\begin{array}{c}\text { Negative } \\
(n=65)\end{array}$ & \\
\hline Age (years) & $67.3 \pm 9.2$ & $67.2 \pm 9.5$ & NS \\
\hline Gender & & & NS \\
\hline Male & 7 & 44 & \\
\hline Female & 4 & 21 & \\
\hline Smoking history & & & NS \\
\hline Smoker & 6 & 42 & \\
\hline Non-smoker & 5 & 23 & \\
\hline Tumor size $(\mathrm{cm})$ & $1.8 \pm 0.5$ & $1.7 \pm 0.7$ & NS \\
\hline EGFR mutations & & & NS \\
\hline Positive & 3 & 19 & \\
\hline Wild-type & 8 & 46 & \\
\hline KRAS mutations & & & NS \\
\hline Positive & 0 & 6 & \\
\hline Wild-type & 11 & 59 & \\
\hline EMLA-ALK & & & NS \\
\hline Positive & 1 & 1 & \\
\hline Negative & 10 & 64 & \\
\hline
\end{tabular}

Data are presented as number of cases or mean \pm standard deviation. MPC, micropapillary component; NS, non-significant; EGFR, endothelial growth factor receptor gene; $K R A S$, Kirsten rat sarcoma viral oncogene homolog; EMLA-ALK, echinoderm microtubule-associated protein-like 4-anaplastic lymphoma kinase fusion gene.

stage IA PA without MPC (Table III). As of December, 2013, $13(17.1 \%)$ patients had succumbed to the disease, with a median follow-up period of 62.0 months; 2 (18.2\%) of the patients with PA-MPC had succumbed to PA during follow-up; $11(16.9 \%)$ patients with PA without MPC had succumbed (7 to PA and 4 to other causes). The 5-year overall survival rates of all pathological stage IA patients $(n=76)$, patients with PA-MPC $(n=11)$, and patients with PA without MPC $(n=65)$ were $82.0,87.5$ and $81.0 \%$, respectively. A total of $13(17.1 \%)$ patients developed disease relapse (4 patients with PA-MPC and 7 patients with PA without MPC). The 5-year disease-free survival rates of all pathological stage IA patients, patients with PA-MPC, and patients with PA without MPC were 80.7, 58.4 and $84.2 \%$, respectively. Patients with PA-MPC exhibited a significantly poorer disease-free survival rate compared with those with PA without MPC (log-rank test, $\mathrm{P}=0.04$ ) (Fig. 3).

\section{Discussion}

The IASLC/ATS/ERS classification is the result of the advances in the research of PA. Although PA-MPC is newly classified in it, its detailed molecular characteristics, including EML4-ALK fusion, have not been determined. In this regard, 


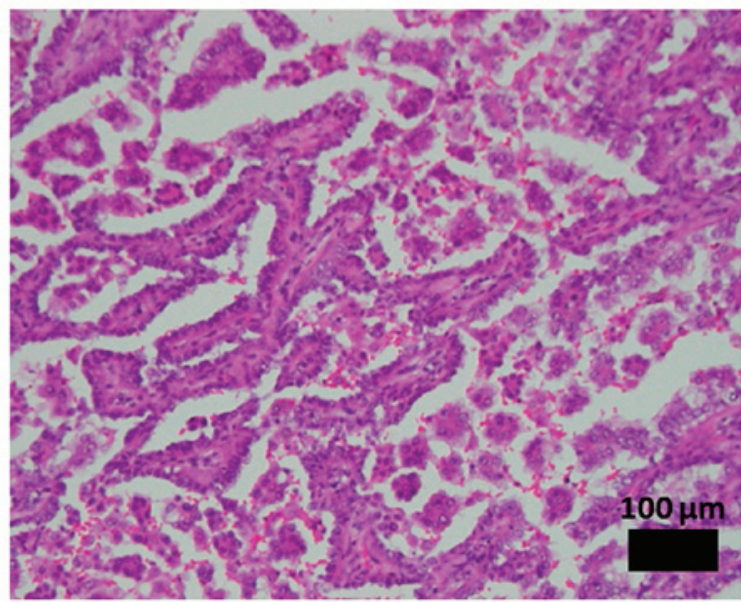

Figure 1. Pulmonary adenocarcinoma with a micropapillary component. Micropapillary growth, in which the papillary tufts lack a centra fibrovascular core and extensively shed within the alveolar spaces (hematoxylin \& eosin staining).
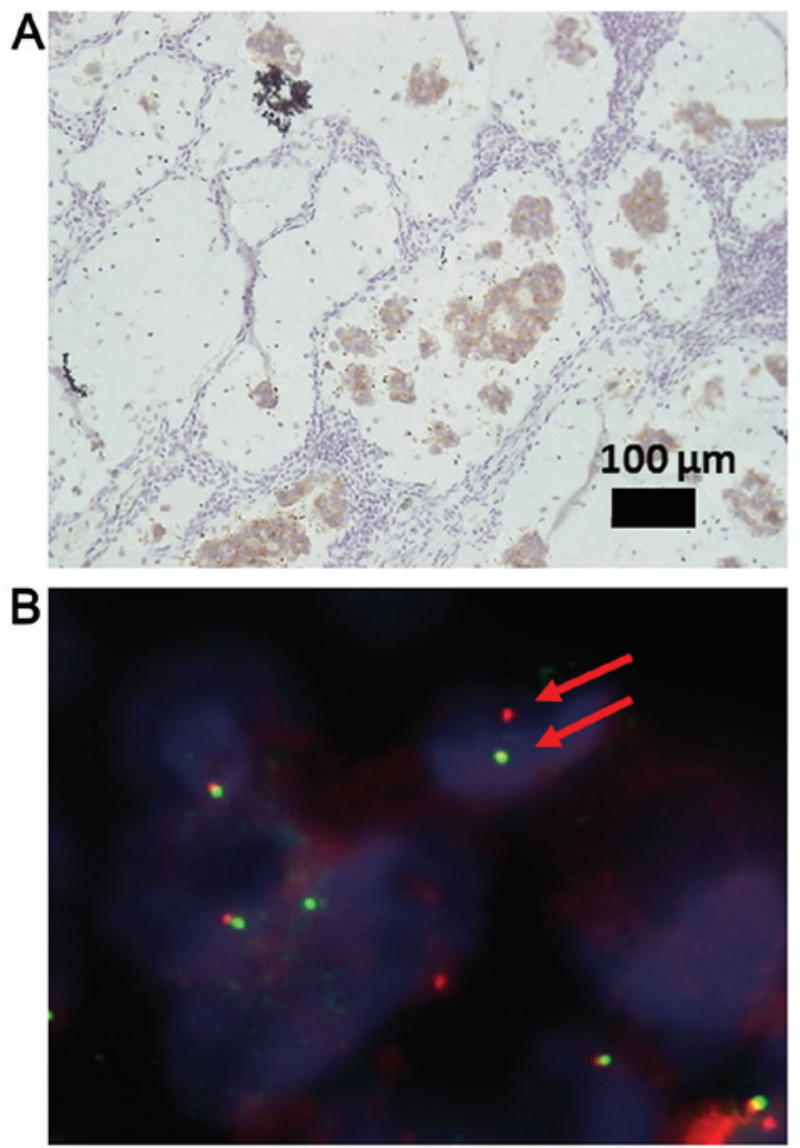

Figure 2. (A) Anaplastic lymphoma kinase (ALK) immunohistochemistry. displaying staining in $A L K$-rearranged lung adenocarcinoma with a micropapillary component. (B) ALK break-apart fluorescence in situ hybridization. Arrows mark split green 5' and orange $3^{\prime}$ signals, indicating $A L K$ rearrangement.

this is a unique report describing a comprehensive gene mutational analysis, including $E M L 4-A L K$ fusion gene, in patients with PA-MPC. In the present study, EML4-ALK fusion genes appeared to occur significantly more frequently in PA-MPC

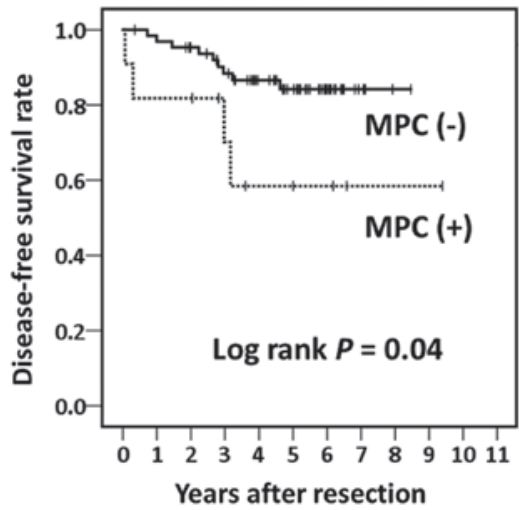

Figure 3. Disease-free survival of pathological stage IA patients with lung adenocarcinoma according to the presence or absence of the micropapillary component (MPC) $(n=76)$. Of note, MPC-positive adenocarcinoma was associated with a significantly poorer prognosis (log-rank test, $\mathrm{P}=0.04)$.

compared with PA without MPC. According to previous reports, the frequency of $E M L 4-A L K$ fusion genes in PA is low $(4.3-6 \%)(23,25,26)$. Furthermore, ALK-positive lung cancers tend to be more common among younger patients and marginally more common in women, which may be associated with the difference in smoking rates between the two genders (27). In our study, the 6 ALK-positive patients included 2 smoking men, 1 non-smoking woman with PA-MPC, and 3 non-smoking women with PA without MPC. The ALK-positive patients were younger than ALK-negative patients (56.0 vs. 66.3 years, respectively; $\mathrm{P}=0.013)$. Inamura et al reported that adenocarcinomas with $E M L 4-A L K$ fusion were predominantly classified as the acinar or papillary subtypes (26). Although our sample size was small, our data suggest that the EML4-ALK fusion gene is one of the most common genetic alterations in PA-MPCs.

As regards the association between PA-MPC and gene status, De Oliveira Duarte Achcar et al reported the genetic alterations of 15 micropapillary-dominant cases, namely $5(33 \%)$ KRAS, 3 (20\%) EGFR and 3 (20\%) BRAF mutations (28). A number of studies regarding patients with PA-MPC reported that they often harbored EGFR mutations $(13,28,29)$. As previously reported, EGFR mutations are common in Asian, female, non-smoker PA patients $(30,31)$ and the frequency of EGFR mutations in Japanese PA patients is $\sim 44 \%$ (32). Conversely, in our series, the prevalence of $E G F R$ mutations in PA was lower (51 of $166,30.7 \%$ ) compared with that previously reported, likely because the population of this study included several smokers (120 of 166, 72.3\%) and men (122 of 166, 73.5\%). In never-smoker patients, the prevalence of the EGFR mutation (24 of 46, 52.2\%) was similar to our previous report (32).

Similar to previous studies (9,11-13), our data suggest a poorer prognosis for PA-MPC compared with that for PA without MPC. Miyoshi et al reported that a higher ratio (6-100\%) of MPC was associated with a poorer prognosis compared with a lower ratio (1-5\%) (12). The ratio of MPC in the 28 PA-MPC cases varied widely (3-80\%) in this study. Our results indicated that PA-MPC had a tendency for relapse, even if the ratio of MPC was low. Thus, clinicians should bear in mind the possibility for metastasis when MPC is present in PA. 
In conclusion, our study suggests that the molecular pathogenesis of PA-MPC may differ from that of other adenocarcinomas, which is associated with its aggressive clinical behavior. Further investigation is required to elucidate the characteristics of PA-MPC and lead to the development of new therapeutic strategies.

\section{Acknowledgements}

We would like to thank Ms. Fumiko Isobe (Department of Thoracic, Breast and Endocrinological Surgery, Okayama University Graduate School of Medicine, Dentistry and Pharmaceutical Sciences, Okayama, Japan) for the preparation of the pathological materials. We would also like to thank Yukinari Isomoto (Central Research Laboratory, Okayama University Medical School, Okayama, Japan) for technical support for the SNaPshot assay. This study was supported by a Grant-in-Aid for Scientific Research from the Japan Society for the Promotion of Science (JSPS KAKENHI grant nos. 22700916 to J.S. and 25293302 to S.T.).

\section{References}

1. Siegel RL, Miller KD and Jemal A: Cancer statistics, 2015. CA Cancer J Clin 65: 5-29, 2015.

2. Malvezzi M, Bertuccio P, Rosso T, Rota M, Levi F, La Vecchia C and Negri E: European cancer mortality predictions for the year 2015: Does lung cancer have the highest death rate in EU women? Ann Oncol 26: 779-786, 2015.

3. Katanoda K, Hori M, Matsuda T, Shibata A, Nishino Y, Hattori M, Soda M, Ioka A, Sobue T and Nishimoto H: An updated report on the trends in cancer incidence and mortality in Japan, 1958-2013. Jpn J Clin Oncol 45: 390-401, 2015.

4. Barlesi F, Scherpereel A, Gorbunova V, Gervais R, Vikström A, Chouaid C, Chella A, Kim JH, Ahn MJ, Reck M, et al: Maintenance bevacizumab-pemetrexed after first-line cisplatin-pemetrexed-bevacizumab for advanced nonsquamous nonsmall-cell lung cancer: Updated survival analysis of the AVAPERL (MO22089) randomized phase III trial. Ann Oncol 25: 1044-1052, 2014.

5. Lynch TJ, Bell DW, Sordella R, Gurubhagavatula S, Okimoto RA, Brannigan BW, Harris PL, Haserlat SM, Supko JG, Haluska FG, et al: Activating mutations in the epidermal growth factor receptor underlying responsiveness of non-small-cell lung cancer to gefitinib. N Engl J Med 350: 2129-2139, 2004.

6. Cadranel J, Mauguen A, Faller M, Zalcman G, Buisine MP, Westeel V, Longchampt E, Wislez M, Coudert B, Daniel C, et al Impact of systematic EGFR and KRAS mutation evaluation on progression-free survival and overall survival in patients with advanced non-small-cell lung cancer treated by erlotinib in a French prospective cohort (ERMETIC project-part 2). J Thorac Oncol 7: 1490-1502, 2012.

7. Travis WD, Brambilla E, Noguchi M, Nicholson AG, Geisinger KR, Yatabe Y, Beer DG, Powell CA, Riely GJ, Van Schil PE, et al: International Association for the Study of Lung Cancer/American Thoracic Society/European Respiratory Society international multidisciplinary classification of lung adenocarcinoma. J Thorac Oncol 6: 244-285, 2011.

8. Yoshizawa A, Motoi N, Riely GJ, Sima CS, Gerald WL, Kris MG, Park BJ, Rusch VW and Travis WD: Impact of proposed IASLC/ATS/ERS classification of lung adenocarcinoma: Prognostic subgroups and implications for further revision of staging based on analysis of 514 stage I cases. Mod Pathol 24: 653-664, 2011.

9. Amin MB, Tamboli P, Merchant SH, Ordóñez NG, Ro J, Ayala AG and Ro JY: Micropapillary component in lung adenocarcinoma: A distinctive histologic feature with possible prognostic significance. Am J Surg Pathol 26: 358-364, 2002.

10. Sánchez-Mora N, Presmanes MC, Monroy V, Moreno N, Lara-Martínez JM, Aladro MH and Alvarez-Fernández E: Micropapillary lung adenocarcinoma: A distinctive histologic subtype with prognostic significance. Case series. Hum Pathol 39: 324-330, 2008
11. Makimoto Y, Nabeshima K, Iwasaki H, Miyoshi T, Enatsu S, Shiraishi T, Iwasaki A, Shirakusa T and Kikuchi M: Micropapillary pattern: A distinct pathological marker to subclassify tumours with a significantly poor prognosis within small peripheral lung adenocarcinoma $(</=20 \mathrm{~mm})$ with mixed bronchioloalveolar and invasive subtypes (Noguchi's type C tumours). Histopathology 46: 677-684, 2005.

12. Miyoshi T, Satoh Y, Okumura S, Nakagawa K, Shirakusa T, Tsuchiya E and Ishikawa Y: Early-stage lung adenocarcinomas with a micropapillary pattern, a distinct pathologic marker for a significantly poor prognosis. Am J Surg Pathol 27: 101-109, 2003.

13. Motoi N, Szoke J, Riely GJ, Seshan VE, Kris MG, Rusch VW, Gerald WL and Travis WD: Lung adenocarcinoma: Modification of the 2004 WHO mixed subtype to include the major histologic subtype suggests correlations between papillary and micropapillary adenocarcinoma subtypes, EGFR mutations and gene expression analysis. Am J Surg Pathol 32: 810-827, 2008.

14. Roh MS, Lee JI, Choi PJ and Hong YS: Relationship between micropapillary component and micrometastasis in the regional lymph nodes of patients with stage I lung adenocarcinoma. Histopathology 45: 580-586, 2004.

15. Su Z, Dias-Santagata D, Duke M, Hutchinson K, Lin YL, Borger DR, Chung CH, Massion PP, Vnencak-Jones CL, Iafrate AJ and Pao W: A platform for rapid detection of multiple oncogenic mutations with relevance to targeted therapy in non-small-cell lung cancer. J Mol Diagn 13: 74-84, 2011.

16. Asano H, Toyooka S, Tokumo M, Ichimura K, Aoe K, Ito S, Tsukuda K, Ouchida M, Aoe M, Katayama H, et al: Detection of EGFR gene mutation in lung cancer by mutant-enriched polymerase chain reaction assay. Clin Cancer Res 12: 43-48, 2006.

17. Tokumo M, Toyooka S, Ichihara S, Ohashi K, Tsukuda K, Ichimura K, Tabata M, Kiura K, Aoe M, Sano Y, et al: Double mutation and gene copy number of EGFR in gefitinib refractory non-small-cell lung cancer. Lung Cancer 53: 117-121, 2006.

18. Toyooka S, Matsuo K, Shigematsu H, Kosaka T, Tokumo M, Yatabe Y, Ichihara S, Inukai M, Suehisa H, Soh J, et al: The impact of sex and smoking status on the mutational spectrum of epidermal growth factor receptor gene in non small cell lung cancer. Clin Cancer Res 13: 5763-5768, 2007.

19. Toyooka S, Tsukuda K, Ouchida M, Tanino M, Inaki Y, Kobayashi K, Yano M, Soh J, Kobatake T, Shimizu N and Shimizu K: Detection of codon 61 point mutations of the K-ras gene in lung and colorectal cancers by enriched PCR. Oncol Rep 10: 1455-1459, 2003.

20. Jokoji R, Yamasaki T, Minami S, Komuta K, Sakamaki Y, Takeuchi $\mathrm{K}$ and Tsujimoto M: Combination of morphological feature analysis and immunohistochemistry is useful for screening of EML4-ALK-positive lung adenocarcinoma. J Clin Pathol 63: 1066-1070, 2010

21. Yoshida A, Tsuta K, Nakamura H, Kohno T, Takahashi F, Asamura H, Sekine I, Fukayama M, Shibata T, Furuta K and Tsuda H: Comprehensive histologic analysis of ALK-rearranged lung carcinomas. Am J Surg Pathol 35: 1226-1234, 2011.

22. Takeuchi K, Choi YL, Soda M, Inamura K, Togashi Y, Hatano S, Enomoto M, Takada S, Yamashita Y, Satoh Y, et al: Multiplex reverse transcription-PCR screening for EML4-ALK fusion transcripts. Clin Cancer Res 14: 6618-6624, 2008.

23. Rodig SJ, Mino-Kenudson M, Dacic S, Yeap BY, Shaw A, Barletta JA, Stubbs H, Law K, Lindeman N, Mark E, et al: Unique clinicopathologic features characterize ALK-rearranged lung adenocarcinoma in the western population. Clin Cancer Res 15: 5216-5223, 2009.

24. Kwak EL, Bang YJ, Camidge DR, Shaw AT, Solomon B, Maki RG, Ou SH, Dezube BJ, Jänne PA, Costa DB, et al: Anaplastic lymphoma kinase inhibition in non-small-cell lung cancer. N Engl J Med 363: 1693-1703, 2010.

25. Paik JH, Choe G, Kim H, Choe JY, Lee HJ, Lee CT, Lee JS, Jheon S and Chung JH: Screening of anaplastic lymphoma kinase rearrangement by immunohistochemistry in non-small cell lung cancer: Correlation with fluorescence in situ hybridization. J Thorac Oncol 6: 466-472, 2011.

26. Inamura K, Takeuchi K, Togashi Y, Hatano S, Ninomiya $H$, Motoi N, Mun MY, Sakao Y, Okumura S, Nakagawa K, et al: EML4-ALK lung cancers are characterized by rare other mutations, a TTF-1 cell lineage, an acinar histology and young onset. Mod Pathol 22: 508-515, 2009.

27. Mitsudomi T, Yatabe Y, Akita H, Genma A, Soda M, Toyooka T, Nakagawa K, Nishio K and Hagiwara K: Guidance for ALK gene testing in lung cancer patients. Biomarker Committee, the Japan Lung Cancer Society, 2011. 
28. De Oliveira Duarte Achcar R, Nikiforova MN and Yousem SA: Micropapillary lung adenocarcinoma: EGFR, K-ras and BRAF mutational profile. Am J Clin Pathol 131: 694-700, 2009.

29. Ninomiya H, Hiramatsu M, Inamura K, Nomura K, Okui M, Miyoshi T, Okumura S, Satoh Y, Nakagawa K, Nishio M, et al: Correlation between morphology and EGFR mutations in lung adenocarcinomas. Significance of the micropapillary pattern and the hobnail cell type. Lung Cancer 63: 235-240, 2009.

30. Tokumo M, Toyooka S, Kiura K, Shigematsu H, Tomii K, Aoe M, Ichimura K, Tsuda T, Yano M, Tsukuda K, et al: The relationship between epidermal growth factor receptor mutations and clinicopathologic features in non-small cell lung cancers. Clin Cancer Res 11: 1167-1173, 2005.
31. Mitsudomi T: Advances in target therapy for lung cancer. Jpn J Clin Oncol 40: 101-106, 2010.

32. Shigematsu H, Lin L, Takahashi T, Nomura M, Suzuki M, Wistuba II, Fong KM, Lee H, Toyooka S, Shimizu N, et al: Clinical and biological features associated with epidermal growth factor receptor gene mutations in lung cancers. J Natl Cancer Inst 97: 339-346, 2005. 